\title{
A NEW METHOD FOR PROTECTION OF SEWAGE COLLECTORS AGAINST CORROSION
}

\author{
Victor Vasiliev', lurii Stolbikhin ${ }^{2}$ \\ 1,2 Saint Petersburg State University of Architecture and Civil Engineering, \\ Vtoraja Krasnoarmejskaja ul. 4, St. Petersburg, 190005, Russia \\ 1 89119311522@bk.ru, 2 Stolbikhin@bk.ru
}

\begin{abstract}
The article provides data on microbiological (gas) corrosion of sewage collectors and structures on them. The results of inspection of Saint Petersburg structures are presented. The findings of the experiment for determination of stability of protective coatings conducted in a pressure suppression chamber in Novosibirsk are given. The known methods of corrosion prevention are considered in the work and a new one is offered, which is aeration of discharge liquid in the pressure suppression chamber by means of natural ejection of air into a penstock. The diagram of the effective construction of the pressure suppression chamber, allowing to implement the offered method, is presented. The carried out experiments on construction modeling of the pressure suppression chamber are described and optimal values of its geometrical parameters are given. The article also presents an engineering solution to collocation of the chamber and a gas cleaning plant on a sewage collector. Economic comparison of the offered method for protection of collectors versus the two most often used ones - fiberglass pipe lining and wall coating with polymer-silicate composition "Konusit KK-10" - is carried out. Cost estimation of fulfillment of the said methods for various diameters of the collector and its length is performed, as well as for various periods of time. Efficiency of the alternative way of corrosion prevention, offered by the authors, is proved.
\end{abstract}

Key words: pressure suppression chamber, microbiological corrosion, gas corrosion, protection against corrosion, examination of protective coatings, modeling of sewage structures

\section{Introduction}

Hundreds of kilometers of underground sewer tunnels and pipelines, mainly made of reinforced concrete, are being operated in Russia. Failures of reinforced concrete collectors and structures on them transporting sewage water, including in Moscow, Saint Petersburg, Krasnodar, Ufa, Naberezhnye Chelny, Kursk, and many other cities of the country, are observed on a regular basis.

Microbiological (also known in literature as gas) corrosion is the main reason for destruction of sewage collectors and structures on them. Reinforced concrete elements of structures and technological equipment of sewage collectors corrode as a result of microbiological corrosion, which disturbs sewage disposal and does damage to the environment (Zhang et al., 2008; Wells and Melchers, 2009; Roz- enthal, 2011; George, 2012). Failure of a collector may have catastrophic effects, lead to people's death and to enormous ecological damage in case of penetration of sewage water into water bodies (Stolbikhin, 2016).

The problem of microbiological corrosion is global. The damage from microbiological corrosion to the world water economy is estimated at billions of euros per year (Zhang et al., 2008; Wells and Melchers, 2009). Only in Germany, expenses connected with repair of corroded sewer structures exceeded USD 50 billion (Hewayde and Nehdi, 2006). In Ukraine, a number of failures in Kiev, Dnepropetrovsk and other cities is recorded only in recent years from 2012 till 2016 (Stolbikhin, 2016).

The examination conducted by us in sewer shafts of Saint Petersburg (see Fig. 1) has confirmed the microbio- 

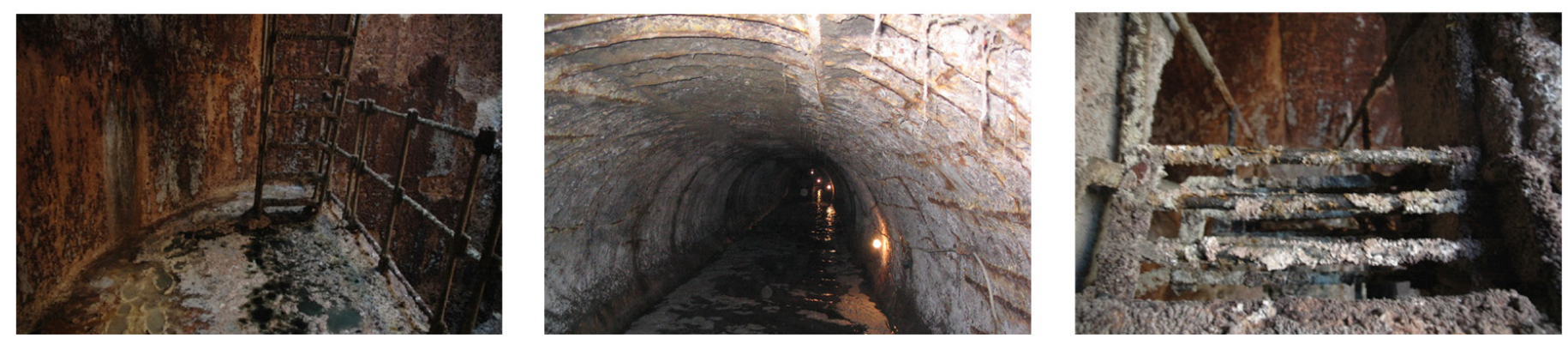

Figure 1. Corroded sewer shafts and collectors in St. Petersburg

logical nature of corrosion damage processes as well as the fact that hydraulic and aerodynamic modes in a shaft have impact on further condition of a collector (Vasilyev et al., 2013). Existence of the penstock bringing sewage waters to the considered structure is also an additional aggravating factor.

Except for shafts, pressure suppression chambers (PSC) accepting waters from penstocks of pump stations and directing them to a collector, are also met on sewage collectors. The data on record-breaking destruction of a collector (in the space of 4 years) in Donetsk, which accepted sewage water from the pressure suppression chamber, sewage water being brought by the penstock of $11 \mathrm{~km}$ in length, is given in the work (Drozd, 2013).

There is a large number of methods for corrosion prevention. However, not all of them find wide application, giving way to so-called passive methods being preferably used. They consist in preliminary choice of resistant materials being in direct contact with corrosive environment. Lining of collectors according to the "pipe-in-pipe" method with using fiberglass pipes as well as application of special protective coatings became widespread.

In 2014, we inspected a section of a tunnel collector in Saint Petersburg protected by fiberglass pipes. The shafts located before and after this section are rapidly corroding as a result of microbiological corrosion while the collector itself is in excellent condition (Fig. 2).
In Novosibirsk, a group of specialists headed by V.M. Vasilyev conducted an examination of concrete samples protected by various materials (Vasilyev et al., 2015). Concrete samples of class B20 and water tightness W8 were coated with various materials to protect them against corrosion. These samples were placed into a pressure suppression chamber and exhibited for 1 year. The average concentration of hydrogen sulfide in the pressure suppression chamber made $\sim 40 \mathrm{mg} / \mathrm{m} 3$. Polymer-silicate composition "Konusit KK-10" (manufactured by MC-Bauchemie, Germany) resulted to be the most effective and the only coating which managed to protect the concrete samples against destruction (see Fig. 3).
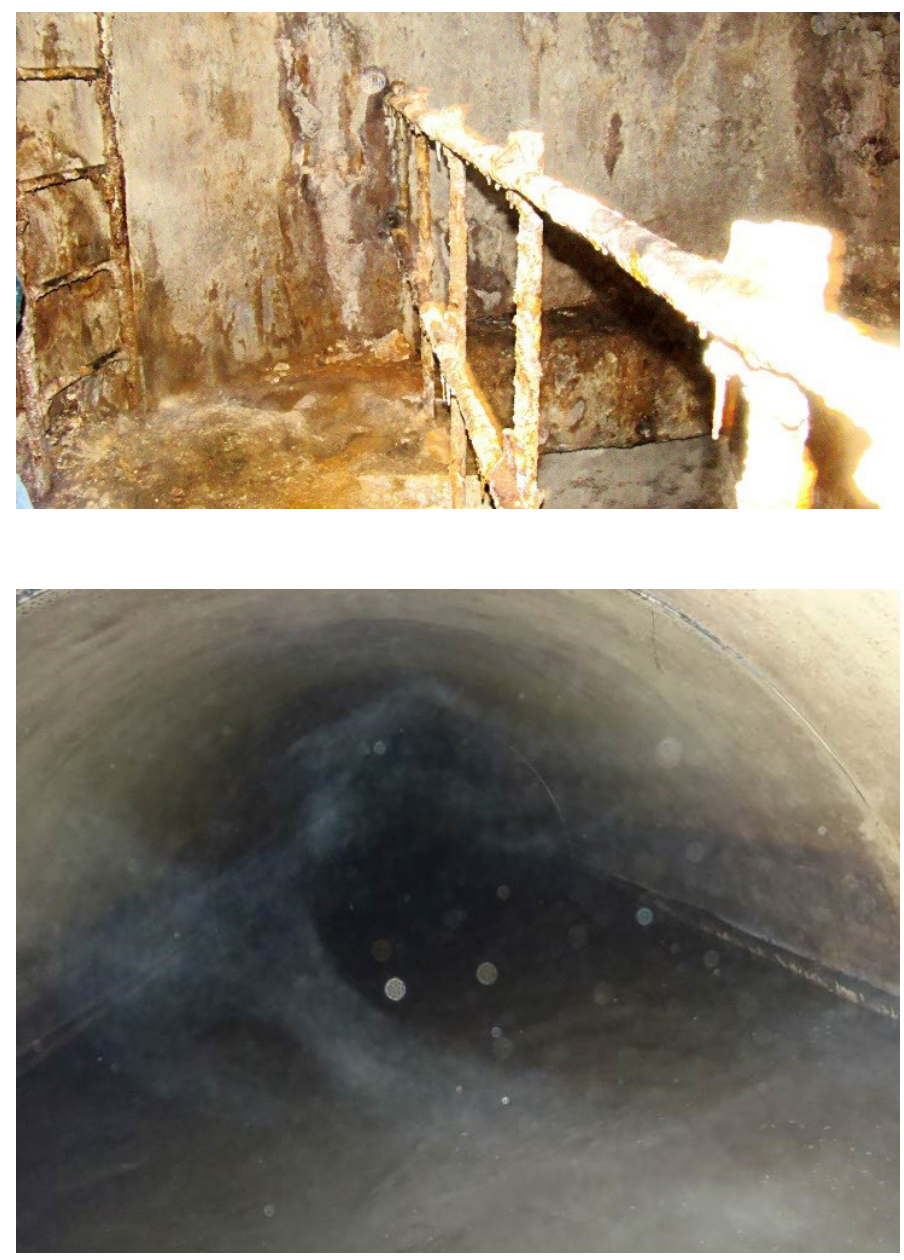

Figure 2. Shafts and a section of the sewage collector connecting them with each other 
Example of the material which failed to protect concrete against destruction - "Ftoronit"
Material which resulted to be effec-

tive against corrosion "Konusit KK-10"
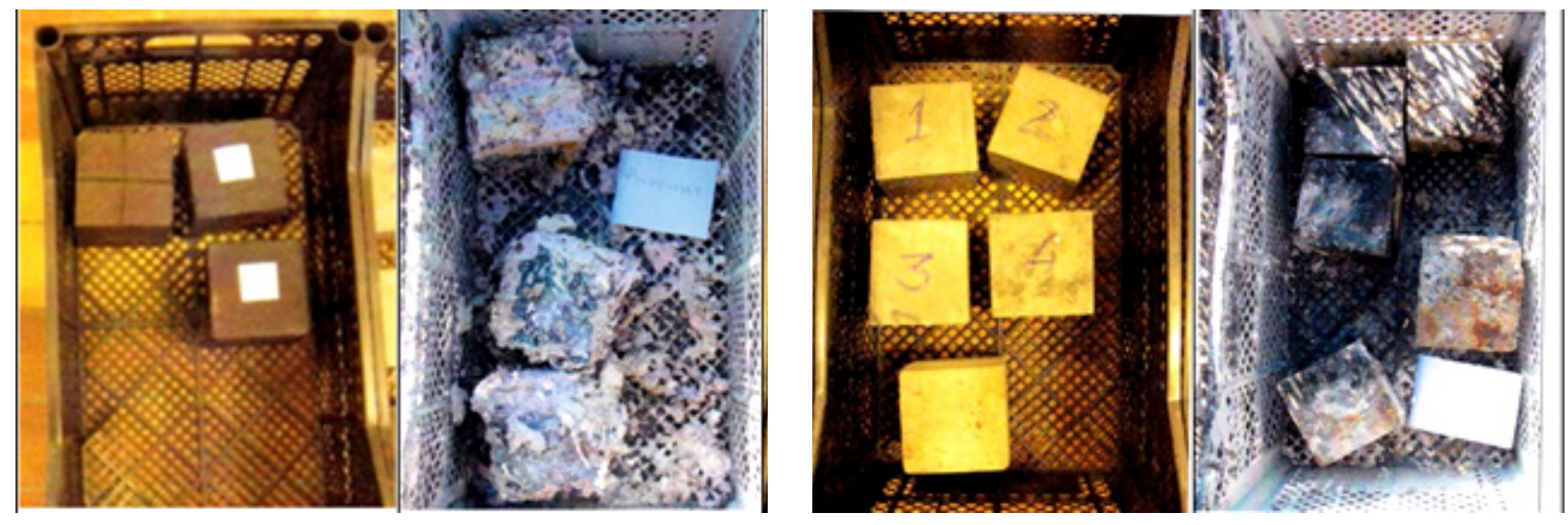

Figure 3. Results of durability examination of protective coatings

Thus, it may be concluded that the above presented methods aimed at separation of a concrete surface from gas environment of collectors and shafts can be rather effective in case of the right choice of a protective material. At the same time, these methods are also rather expensive. Therefore, researchers all over the world are in search for alternative ways of corrosion prevention. In particular, some methods of addition of various chemical agents into sewage water are being widely investigated. Thus, American researchers report a possibility of adding iron chloride (Lynne et al., 2009), whereas Indian researchers - a possibility of adding Fe3+ (Zhang et al., 2009). However, dosing of any chemical agents is also connected with very considerable expenses, especially in case of transportation of discharge liquid in large volumes. For example, more than 2 million $\mathrm{m}^{3}$ of sewage water is drained daily in Saint Petersburg, which will demand enormous amounts of chemical agents. Therefore, development of new alternative methods for corrosion prevention remains a vital task.

\section{Materials and methods}

The method of saturation of discharge liquid with aerial oxygen is especially interesting among methods of fight against microbiological corrosion. The way of saturation of the liquid with aerial oxygen (stream aeration) is based on the idea that in case of saturation of discharge liquid with dissolved oxygen in sufficient concentrations, oxidation of hydrogen sulfide formed due to the action of sulfate-reducing bacteria will happen. Concentrations of dissolved oxygen higher than $0.5 \mathrm{mg} / \mathrm{L}$ can prevent from formation of sulfides in general.

Researchers N. Tanaka and T. Hvitved-Jacobsen conducted an examination in Kawasaki (Japan) on the process of forced injection of aerial oxygen into a penstock (Tanaka, 2000). In these conditions, concentrations of dissolved oxygen of $0.2-1.0 \mathrm{mg} / \mathrm{L}$ were recorded and the process of sulfide formation was slowed down or sup- pressed completely. However, forced injection of air into a penstock requires considerable expenses of electric power due to work of a compressor installation.

In this regard, it was offered to implement the way of saturation of discharge liquid with aerial oxygen by means of its natural ejection to the pipeline, which can be executed in the pressure suppression chamber. A similar experiment was carried out by V.M. Vasilyev in Novosibirsk, having given positive results. Accordingly, we have developed an effective construction of a pressure suppression chamber. The diagram of the effective construction of pressure suppression chamber is presented in Fig. 4.

The structure functions as follows. Water goes to the ascending pipe (2) over the supply pressure pipeline (1) and gets to the damping basin (4). The horizontal section of the pipeline and the ascending pipe are interconnected to each other either by means of the pipe bend (2) having a certain radius of inlet Rinl, or they can be connected at a right angle without a curve. The stream separation happens in the area of interface of these pipelines and a zone of reduced pressure forms. The ejecting pipeline (8) being vented to atmosphere is brought here. The ascending pipe (2) is embedded on the value $\Delta$ in relation to the water level in the damping basin (4) formed by means of the overflow wall (5). The process of mixture of water and air followed by increase in concentration of dissolved oxygen in the drain happens in the damping basin (4). Further, the aerated discharge liquid flows out through the spillway into the damping pan (6) and goes to the discharge collector (7).

Modeling of structures was carried out to establish the most favorable ratios of diameters of pipelines, their linear parameters in relation to other elements of the chamber, optimum size of the structure in the plan and according to height. The ejected air flow was the main criterion for the structures to be compared among themselves. The larger its value at equal water flows is, the higher oxygen concentration at the outlet of the of pressure suppression chamber will be (Stolbikhin, 2015). 


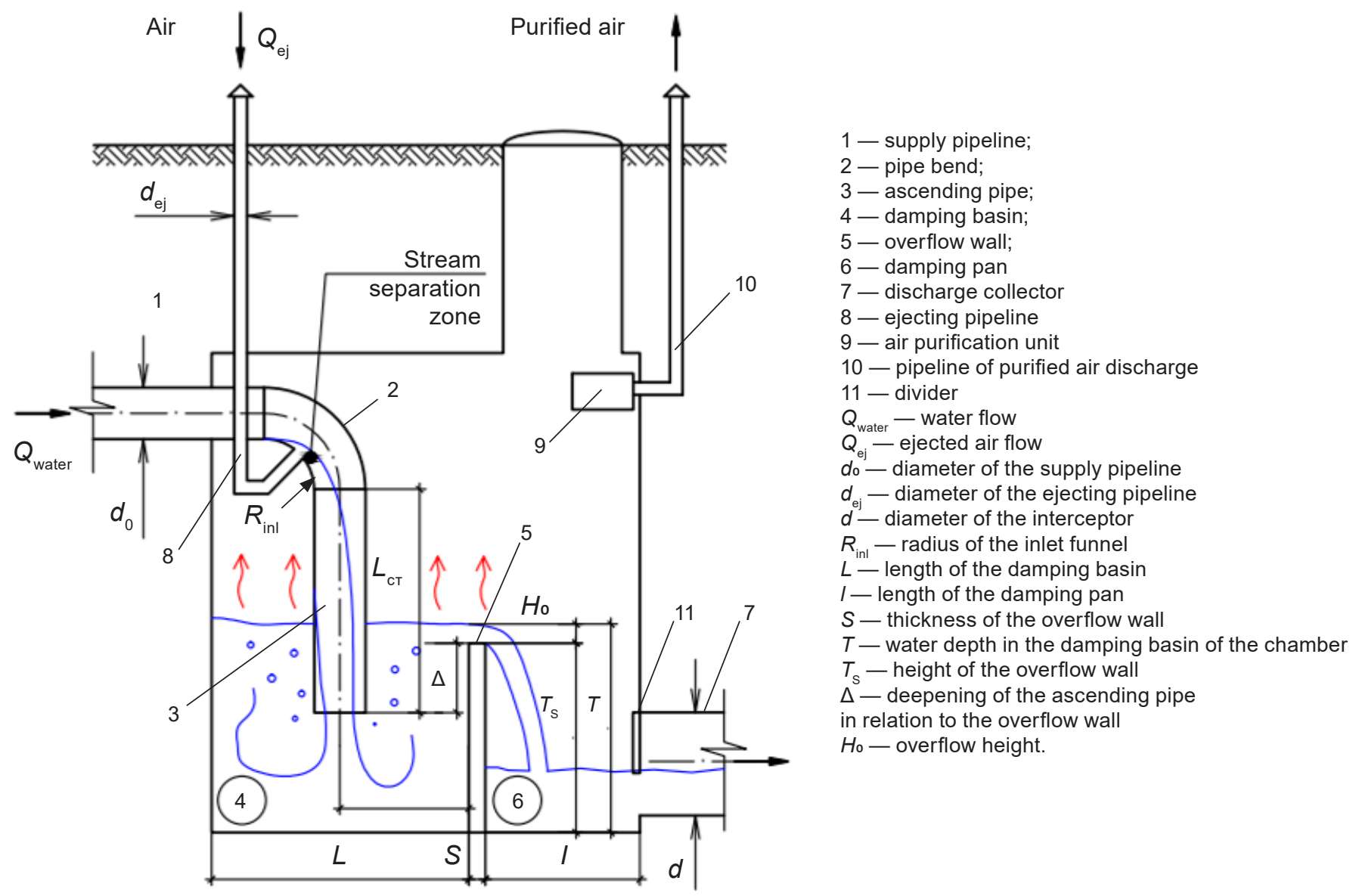

Figure 4. Diagram of the effective construction of pressure suppression chamber

Modeling was carried out by means of mathematical models developed in the ANSYS program complex and the accuracy of calculations was confirmed on a physical model created in the laboratory of hydraulics of the Chair of Water Usage and Ecology at the Saint Petersburg State University of Architecture and Civil Engineering (SPSUACE).

\section{Findings}

Work with the physical model of the pressure suppression chamber showed that the air is naturally carried away to the stream separation zone of the supply pipeline of the pressure suppression chamber. The flow of the air entering the system was measured by a gas meter. Further, the mathematical model of the pressure suppression chamber, identical to its physical prototype by its size, was created. As a result, full compliance of the findings obtained on both models was reported (see Fig. 5).

Further, various full-scale models of pressure suppression chambers were developed and series of numerical experiments were conducted. As a result, optimal values of various parameters of chambers were established.

The conducted examination showed that the optimal values for a pressure suppression chamber are the following:

- deepening: $\Delta=0 \mathrm{~mm}$;

— radius of inlet: $\operatorname{Rinl}=0 \cdot \mathrm{d} \mathrm{mm}$;
- diameter of the ejecting pipeline: dej $=1 / 3 \cdot d 0$;

- size of the damping basin in the plan: minimum allowed, according to regulations being in force in one or another country, based on a possibility of operation of the structure;

- depth of the pressure suppression chamber: depends on the water flow (see Table 1).

Table 1. Recommended value of $T_{\mathrm{S}}$ for PSC with $d_{0}=200-800 \mathrm{~mm}$

\begin{tabular}{|c|c|c|c|c|c|c|}
\hline $\begin{array}{c}\text { Diameter of the } \\
\text { supply pipeline, mm }\end{array}$ & 200 & 300 & 400 & 500 & 600 & 800 \\
\hline $\begin{array}{c}\text { Maximum water } \\
\text { consumption, L/s }\end{array}$ & 63 & 200 & 375 & 575 & 800 & 1500 \\
\hline $\begin{array}{c}\text { Height of the over- } \\
\text { flow wall TS, mm, } \\
\text { for PSC with lining }\end{array}$ & 500 & 700 & 1000 & 1100 & 1200 & 2100 \\
\hline $\begin{array}{c}\text { Height of the overflow } \\
\text { wall TS, mm, for PSC, } \\
\text { having open surface }\end{array}$ & 800 & 1000 & 1300 & 1400 & 1500 & 2550 \\
\hline
\end{tabular}

The given above parameters guarantee saturation of discharge liquid with aerial oxygen to the required concentrations.

The use of the pressure suppression chambers of the offered structure, provided with the device for air ejection and 

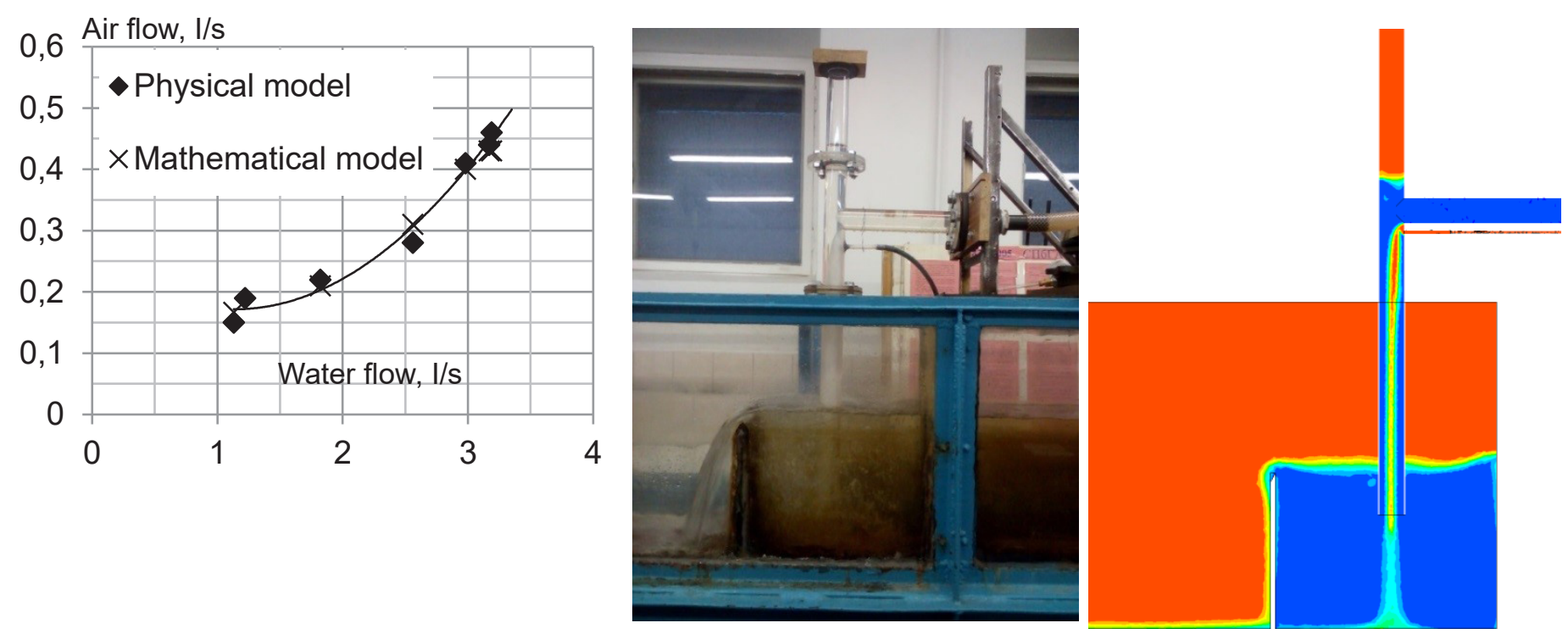

Figure 5. comparison of the mathematical and the physical models

saturation of sewage water with oxygen, will be effective for protection of structures only in combination with discharge of dirty air and its exclusion from the collector after the PSC.

Emission of polluted air into the atmosphere is impossible (GN 2.1.6.695-98); therefore, it is necessary to provide its purification by means of a special gas-purifying unit (see Fig. 6). In this case, an engineering solution with the use of a plasma and catalytic reactor as a gas-purifying unit is shown in Fig. 6. It must be noted that the use of a similar reactor, as well as any other unit for air purifi- cation, supposes inclusion of a fan into the technological scheme, as all gas-purifying units have high aerodynamic resistance.

The article provides data on economic comparison of the method offered by V. Vasilyev and Yu. Stolbikhin with methods of passive protection of sewage collectors. We consider the simplified task to protect a collector of a certain length and diameter (see Fig. 7); the following methods for protection of the structure against corrosion are compared on the basis of economic calculation:

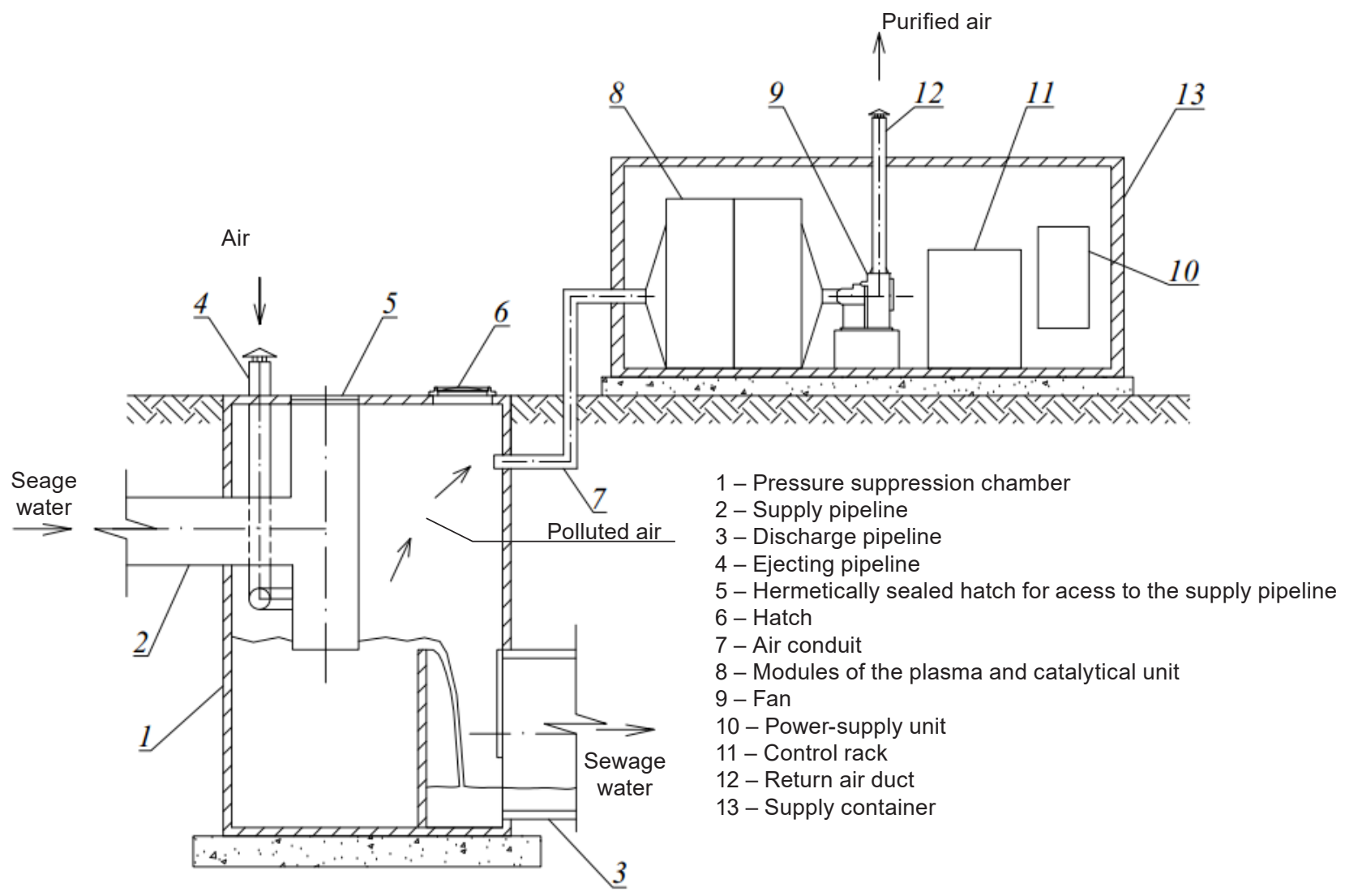

Figure 6. Complex "pressure suppression chamber - gas-purifying unit" 


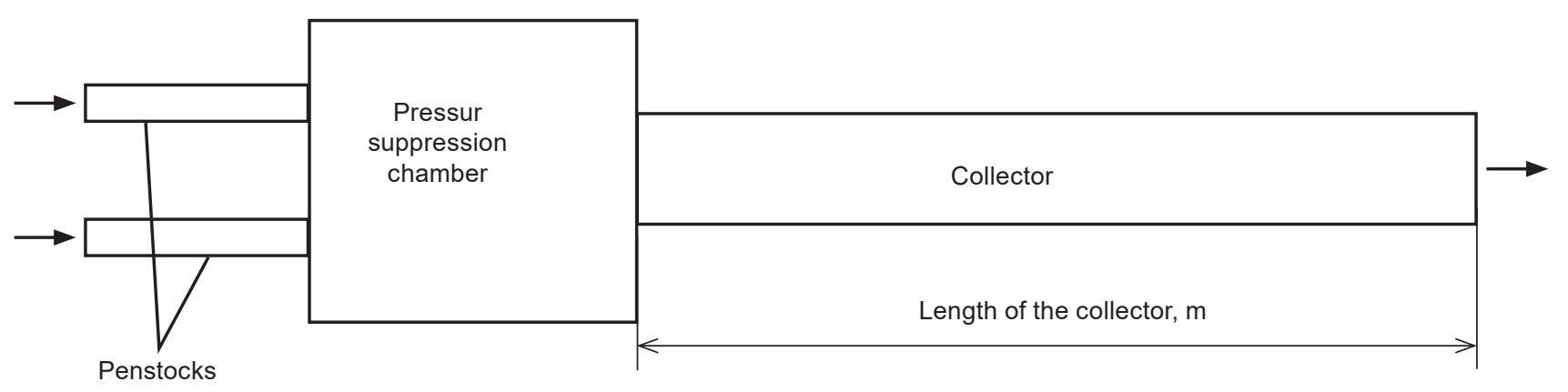

Figure 7. Diagram for economic comparison of options for protection of the collector behind the pressure suppression chamber against corrosion

1) Use of the complex "pressure suppression chamber - gas-purifying unit";

2) Protection of the collector by the "Pipe-in-pipe" method using pipes manufactured by "Hobas";

3) Coating walls of the tunnel with material "Konusit KK-10".

The assessment is made on the basis of expenses (capital and operational) for pipelines of a different diameter and length for various periods of time (up to 100 years).

The current task can be formulated as follows. There is a reinforced concrete pressure suppression chamber and a reinforced concrete discharge collector. Four options of the flow rates, for which this system is intended, are considered. A diameter of the collector is determined by the estimated flow rate and given in Table 2.

Table 2. Considered options for the statement of the problem

\begin{tabular}{|c|c|c|}
\hline Option No. & Estimated flow rate, L/s & Diameter of the collector, $\mathrm{mm}$ \\
\hline Option 1 & 750 & 800 \\
\hline Option 2 & 1150 & 1000 \\
\hline Option 3 & 1600 & 1300 \\
\hline Option 4 & 3000 & 2000 \\
\hline
\end{tabular}

Results of the economic calculations are presented on diagrams in Figures 8 and 9.

Figure 8 presents comparison of three methods for protection of a collector of 250 meters in length with a diameter of $800-2000 \mathrm{~mm}$ during the period of time of 100 years. The lines corresponding to the use of the method 1 (complex "PSC - gas-purifying unit") have an increasing character due to operational costs. The two other methods do not require any operational costs on condition of a high level of construction works; thus, graphically the methods 1 and 2 are presented in the form of horizontal straight lines reflecting the final cost of protection of a collector of a specific length and diameter.

It can be seen from the diagram that at the initial stage the use of the complex "PSC - gas-purifying unit" proved to be most cost-effective for all options of diameters of the collector; however, in the course of time other protection methods are becoming even more cost-effective. Table 3 presents time duration, which is required for the methods 2 and 3 to become more cost-effective than the method 1 .
Table 3. Time required for a method to become more cost-effective than the complex "PSC - gas-purifying unit" for a collector with the length of $250 \mathrm{~m}$

\begin{tabular}{|c|c|c|}
\hline Diameter option & $\begin{array}{c}\text { Lining of the } \\
\text { collector by } \\
\text { "Hobas" pipelines }\end{array}$ & $\begin{array}{c}\text { Coating of walls of } \\
\text { the tunnel with "Ko- } \\
\text { nusit KK-10" material }\end{array}$ \\
\hline $\begin{array}{c}\text { Option } 1 \\
(\mathrm{~d}=800 \mathrm{~mm})\end{array}$ & 25 years & 18 years \\
\hline $\begin{array}{c}\text { Option } 2 \\
(\mathrm{~d}=1000 \mathrm{~mm})\end{array}$ & 28 years & 7 years \\
\hline $\begin{array}{c}\text { Option } 3 \\
(\mathrm{~d}=1300 \mathrm{~mm})\end{array}$ & 42 years & 23 years \\
\hline $\begin{array}{c}\text { Option } 4 \\
(\mathrm{~d}=2000 \mathrm{~mm})\end{array}$ & - & 37 years \\
\hline
\end{tabular}

It follows from the presented data that for collectors of a small length the method 1 ("PSC - gas-purifying unit") can be used as a temporary solution allowing to solve the corrosion problem till the moment, when the operating organization has funds for protection according to the methods 1 or 2. Moreover, in all cases protection of the pipeline according to the method 2 (lining by fiberglass pipes, "Hobas") proves to be more expensive than coating of walls of the tunnel with "Konusit KK-10" material (method 3). At the same time namely the method 2 is the most reliable of all the considered ones.

Figure 9 presents comparison of the protection methods for collectors with a various length (from 250 to $2000 \mathrm{~m}$ ) during 100 years. It can be seen from the diagram that at certain length values of a collector method 1 proves to be the most cost-effective despite all possible operational costs. Table 4 presents the length value of the collector, at which the method 1 proves to be economically more effective than the methods 2 and 3.

Table 4. Length of the collector, at which methods prove to be less cost-effective than the use of the method "PSC gas-purifying unit"

\begin{tabular}{|c|c|c|}
\hline Protection method & $\begin{array}{c}\text { Lining of the } \\
\text { collector by } \\
\text { "Hobas" pipelines }\end{array}$ & $\begin{array}{c}\text { Coating of walls of } \\
\text { the tunnel with "Ko- } \\
\text { nusit KK-10" material }\end{array}$ \\
\hline Option $1(\mathrm{~d}=800 \mathrm{~mm})$ & $915 \mathrm{~m}$ & $1165 \mathrm{~m}$ \\
\hline Option $2(\mathrm{~d}=1000 \mathrm{~mm})$ & $835 \mathrm{~m}$ & $1275 \mathrm{~m}$ \\
\hline Option $3(\mathrm{~d}=1300 \mathrm{~mm})$ & $585 \mathrm{~m}$ & $975 \mathrm{~m}$ \\
\hline Option $4(\mathrm{~d}=2000 \mathrm{~mm})$ & - & $650 \mathrm{~m}$ \\
\hline
\end{tabular}


- Option 1 - PSC

- Option 1 - Hobas 250m

Option 3 - Hobas $250 \mathrm{~m}$

- Option 1 - Konusit KK-10 250 m

- Option 3 - Konusit KK-10 250 m

Total cost, mln rub

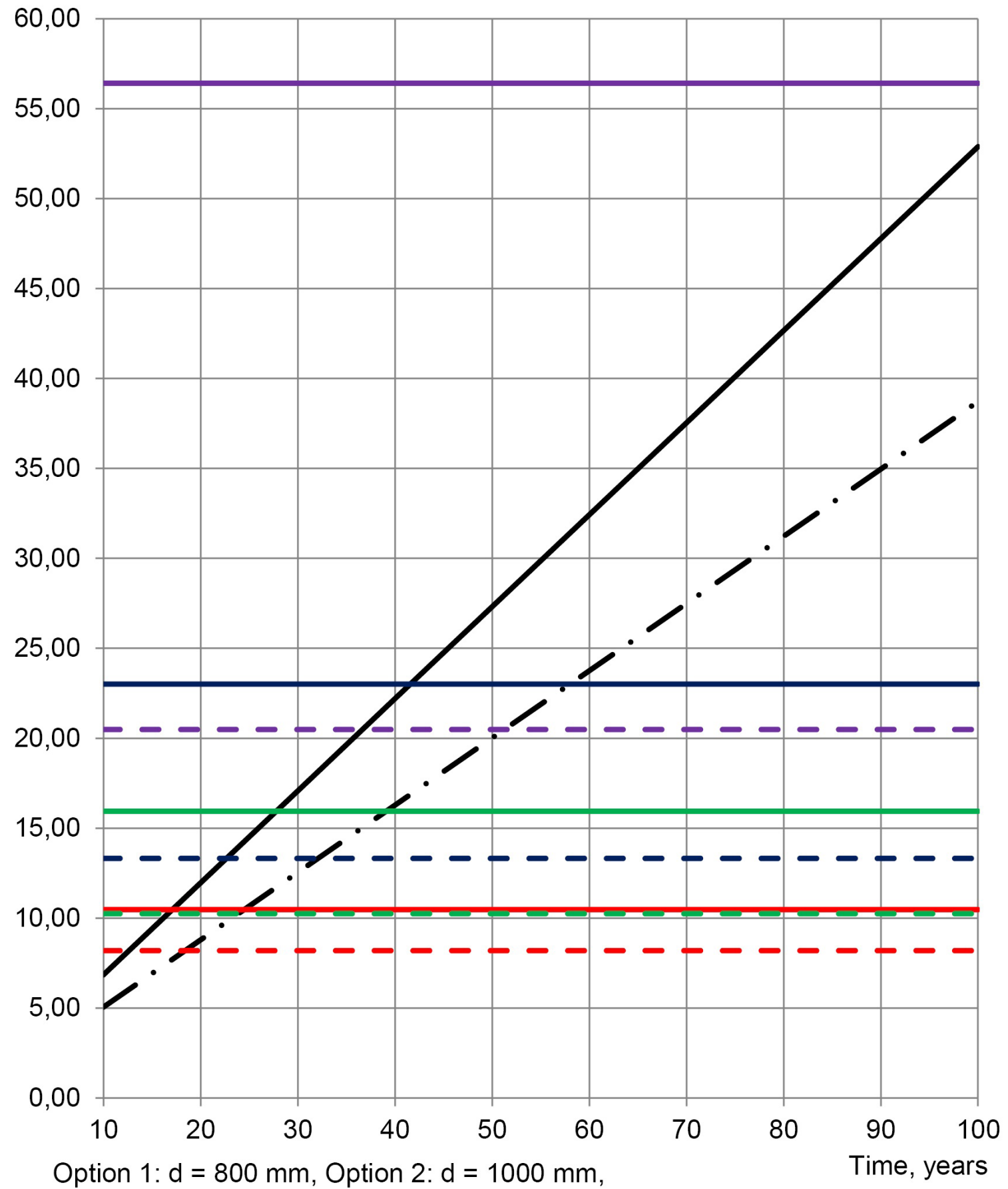

Option 3: $d=1300 \mathrm{~mm}$, Option 4: $d=2000 \mathrm{~mm}$ 
Total cost, mln rub

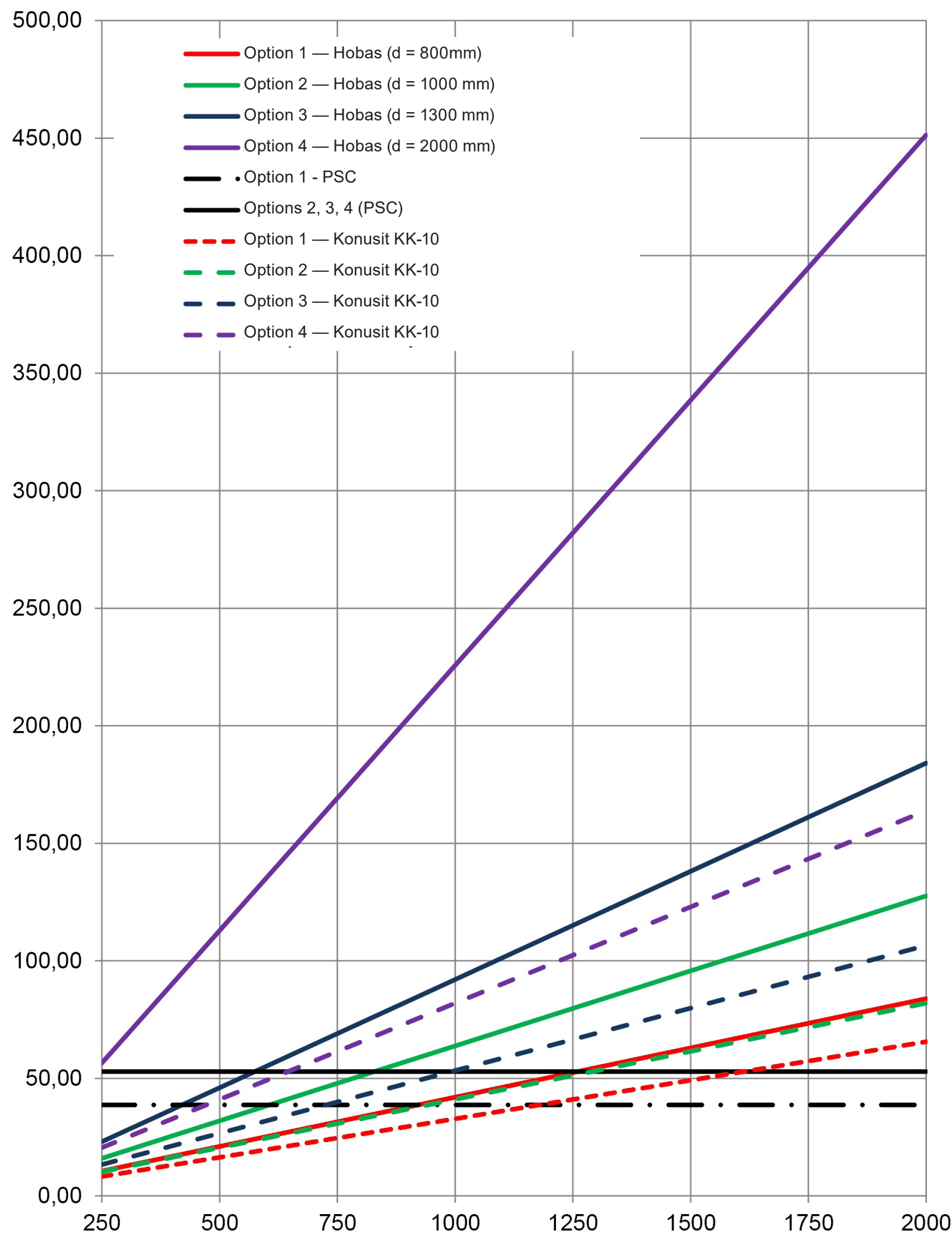

Option 1: $\mathrm{d}=800 \mathrm{~mm}$, Option 2: $\mathrm{d}=1000 \mathrm{~mm}$, Option 3: $d=1300 \mathrm{~mm}$, Option 4: $d=2000 \mathrm{~mm}$

Collector length, $m$

Figure 9. Comparison of methods for protection of sewage collectors of various length during 100 years 
It can be seen from the submitted data that during 100 years the method offered by the author for pipelines with the length of more than $1 \mathrm{~km}$ on the average proves to be more effective. And the larger diameter of the collector is, the more cost-effective the use of the proposed solution becomes. However, it should be noted that the forecast for the next 100 years cannot be accurate in conditions of ever-changing technologies. Therefore, all the three considered options of protection can be applied, the choice depending on specific conditions. In general, protection with the use of the complex "PSC - gas-purifying unit" is the most cost-effective in the majority of cases, but, on the other hand, the least tested in practice, which can be an obstacle to wide use of the method in the near future. The use of fiberglass pipes for lining of collectors is a measure providing full protection against corrosion and guaranteed excellent results. But, this method requires the largest capital investments. Coating of walls of the collector with "Konusit KK-10" material occupies the average niche according to cost; however, in this case the quality of construction works prevails, and in case of violation of technology the desired results will not be obtained. Besides, in this case the service life during 100 years is not guaranteed.

In conclusion, it must be noted that the method of aeration of discharge liquid offered by the authors allows to solve the corrosion problem in the collector behind the pressure suppression chamber; however, the pressure suppression chamber itself needs protection as well, and in this case it is best of all to use lining of its surface by pol- yethylene sheets or coating of the concrete surface with composition "Konusit KK-10".

\section{Conclusions}

Microbiological (gas) corrosion is a serious problem for both Russian and global engineering infrastructure.

The inspection of sewage structures (deep-level tunnels and shafts), carried out by the authors of this work in Saint Petersburg, showed that lining of collectors by fiberglass pipes is an effective method for protection against corrosion.

The experiment conducted by the authors in the pressure suppression chamber in Novosibirsk showed that the use of polymer-silicate composition "Konusit KK-10" can also be an effective method for protection of sewage collectors and structures on them.

The authors offered a new alternative method for corrosion prevention based on aeration of discharge liquid in the pressure suppression chamber, which efficiency was proved.

The engineering solution on protection of sewage collectors against the process of microbiological (gas) corrosion is presented: the complex "PSC - gas-purifying unit".

The economic comparison of methods for protection of the collector was made and the economic efficiency of the complex "Pressure suppression chamber - gas-purifying unit" was proved for pipelines of a small length for the period of 20-40 years as a temporary solution, and for pipelines of a bigger length (more than $1 \mathrm{~km}$ ) for the period of 100 years as a permanent solution.

\section{References}

Drozd G (2013) Korrozionnoe razrushenie, prognozirovanie stepeni agressivnosti ekspluatatsionnoi sredy i obespechenie nadezhnosti kanalizatsionnykh kollektorov na stadii proektirovaniya [Corrosion damage, forecasting of aggression degree of operational environment and reliability assurance of sewage collectors at the design stage]. Voda i ekologiya: problemy i resheniya [Water and ecology: problems and solutions],1: 40-58.

George RP, Vinita Vishwakarma, Samal SS, Kamachi Mudali U (2012) Current understanding and Future Approaches for Controlling Microbially Influenced Concrete Corrosion: A Review. Concrete research letters, 3(3): 491-506

Hewayde E, Nehdi M (2006). Effect of geopolymer cement on microstructure, compressive strength and sulphuric acid resistance of concrete. Magazine of Concrete Research, 58(5): 321-331.

Lynne SN, Grubb BP, Welle TJ, Hausauer JA (2009) Case Study - Fargo, North Dakota: Hydrogen Peroxide for Regeneration of Ferrous Chloride, an Innovative Approach to Hydrogen Sulfide Control. Proceedings of the Water Environment Federation, WEFTEC 2009: Session 21 through Session 30, pp. 1119-1131.

Minzdrav Rossii (Ministerstvo zdravookhraneniya Rossiiskoi Federatsii) (1998) GN 2.1.6.695-98: PREDEL"NO DOPUSTIMYE KONTsENTRATsII (PDK) ZAGRYaZNYaYuShchIKh VEShchESTV V ATMOSFERNOM VOZDUKhE NASELENNYKh MEST [MAXIMUM ALLOWABLE CONCENTRATIONS (MACs) OF POLLUTANTS IN THE AIR OF RESIDENTIAL AREAS]. MinZdrav Rossii, Moscow, RF (in Russian).

Rozenthal N (2011) Korroziya i zashchita betonnykh i zhelezobetonnykh konstruktsii sooruzhenii ochistki stochnykh vod [Corrosion and protection of concrete and reinforced concrete structures of wastewater treatment plants]. Beton i zhelezobeton. Oborudovanie, materialy, tekhnologiya [Concrete and reinforced concrete. Equipment, materials, technology], 1: 96-103 (in Russian).

Stolbikhin Yu (2015) Issledovanie protsessa ezhektsii vozdukha v kamere gasheniya napora [Examination of the air ejection process in a pressure suppression chamber] Vestnik grazhdanskikh ingenerov [Bulletin of Civil Engineers], 3(50): 202-210.

Stolbikhin Yu (2016). Razrabotka metodov predotvrashcheniya korrozii kanalizatsionnykh kollektorov i sooruzhenii na osnove sovershenstvovaniya kamer gasheniya napora [Development of methods for corrosion prevention of sewage collectors and structures on the basis of improvement of pressure suppression chambers]. PhD thesis, Saint Petersburg State University of Architecture and Engineering, Saint Petersburg, Russia (in Russian). 
Tanaka N, Hvitved-Jacobsen T, Ochi T, Sato N (2000) Aerobic-anaerobic microbial wastewater transformations and reaeration in an air-injected pressure sewer. Water Environment Research, 72(6): 65-674.

Vasilyev V et al. (2013) Razrushenie kanalizatsionnykh tonnelei i sooruzhenii na nikh vsledstvie mikrobiologicheskoi korrozii [Destruction of sewer tunnels and structures on them because of microbiological corrosion]. Vodosnabzhenie i sanitarnaya tekhnika [Water supply and sanitary engineering], 9: 67-76.

Vasilyev $\vee$ et al. (2015) Metody antikorrozionnoi zashchity tonnel'nykh kollektorov i sooruzhenii na nikh [Methods for anticorrosion protection of tunnel collectors and structures on them] Vodosnabzhenie i sanitarnaya tekhnika [Water supply and sanitary engineering],1: 202-210.

Wells P, Melchers R (2009) Factors involved in the long term corrosion of concrete sewers (Paper 54). In Conference Proceedings: Corrosion and Prevention 2009: The Management of Infrastructure Deterioration. Coffs Harbour, Australia, pp. 15-18.

Zhang L, De Schryver P, De Gusseme B, Verstraete W (2008) Chemical and biological technologies for hydrogen sulphide emission control in sewer systems: A review. Water Research, 42: 1-12.

Zhang L, Keller J, Yuan Z, (2009) Inhibition of sulfate-reducing and methanogenic activities of anaerobic sewer biofilms by ferric iron dosing. Water Research, 43(17): 4123-4132. 